\title{
The Separate Undergraduate Library
}

\begin{abstract}
A new phenomenon came into being in 1949 with the opening of the first separate library for undergraduates in a university. Many have now been built, and more are planned. This paper discusses some of the thinking that preceded their development.

It analyzes three of them-Lamont, Michigan, and UCLA-in some detail, and speculates as to their future.
\end{abstract}

O

VER THE PAST eighteen years, a number of large universities in the United States have established separate libraries for undergraduate students. Either a new separate building has been constructed specifically for the purpose of serving the undergraduates or an old building has been converted into a discrete library to provide a special collection, special facilities, and services specifically oriented to the undergraduate students. Of late, more and more universities appear to be following this pattern so that it would seem that a definite trend among academic institutions has been started.

This development appears to be the result of several concurrent factors. There has been the recognition of the need for improved service to the undergraduate student, who has been swallowed up in great multi-universities and overwhelmed by vast research collections. In constant competition with more experienced and knowledgeable graduate students, he has come out on the short end of library service. Perhaps an even greater impetus toward establishing another library building on large university campuses has been the great growth of universities over the past few decades, especially since the end of World War II. A tremendous increase

Mrs. Mills is Children's Librarian at the Los Angeles Public Library. in enrollment of students, at both the graduate and undergraduate level, has caused critical crowding in libraries and brought an urgent and imperative need for more space. Steadily growing research collections have added their pressure for needed room and stack space. The establishment of research centers and graduate schools has brought increasing demands on library facilities from faculties and scholars. These factors-the need for improved service to undergraduates and critical space problems-have worked together to bring about the development of the separate undergraduate library.

This paper proposes to offer a study of that development, beginning with a listing of present undergraduate libraries, continuing with a study of the background conditions that led to the establishment of separate undergraduate libraries, making a survey of three libraries-Lamont, Michigan, and UCLAwhich can serve as types, and concluding with an attempt at evaluating the merits of such a library.

Before entering into the discussion of this paper, however, it must be made clear that it concerns only the undergraduate library which has been set up in its own separate building. There have been other types of undergraduate library service provided by universities, but they are not to be confused here with that of the separate library. Per- 
haps a few words should be said about the other types first.

Many libraries have set aside separate collections for undergraduates in special quarters within the main university library building. Such a plan was successfully developed at Columbia, where a collection of thirty-five thousand volumes, known as the Columbia College library, was set up in special rooms. ${ }^{1}$ For a period of eighteen years-from 1931 to $1949,{ }^{2}$ a similar college library existed at the University of Chicago with a collection of about twenty thousand volumes. At the present time, the University of Cincinnati has a comparable scheme with a separate collection of about ten thousand volumes tied in physically with special collections. ${ }^{3}$ Rice University also has developed a specific undergraduate collection which is housed as an entity in a separate room. ${ }^{4}$

This type of arrangement apparently has satisfied the specific needs of these institutions for serving their undergraduates. In many institutions, a system of departmental and college or school libraries, which vary in size and extent according to the needs of the institution, also exists. Other institutions have specialized provisions for undergraduates, such as special reading rooms. A number of other universities have set up small libraries in their residence halls.

The idea of separate service for undergraduates, therefore, is not new. The concept of a separate library building to serve as an individually distinct library for the undergraduate and to provide him with his own environment and service is a relatively new development which began in 1949, however, and it

\footnotetext{
1 Wyman S. Parker, "The Vital Core," $C R L$, XIV (July 1953), 274.

2 Stanley E. Gwynn, "The College Library at the University of Chicago," CRL, XIV (July 1953), 267. Parker, loc. cit.

"W. S. Dix, "Library Service to Undergraduates: Undergraduate Libraries," CRL, XIV (July 1953), 271.
}

is this trend which is the concern of this paper.

\section{Present Existing or Planned UNDERGRADUATE LIRRARIES}

The first undergraduate library to be built was the Lamont library, which opened at Harvard in $1949 .{ }^{5}$ With the opening of the Lamont, a major change was brought about in library service to undergraduates and a pattern was set that would be followed by an increasing number of large universities in succeeding years.

On January 7,1952 , the University of Minnesota opened a new freshmansophomore library in Johnston Hall, which was connected to the main library by a tunnel. This library was oriented specifically toward the undergraduate student and was an attempt to bring him into closer, open-stack contact with the library materials which he would need to use immediately. ${ }^{6}$

The University of Michigan opened its undergraduate library in 1958 and led the way for other large state universities. As an example of effective and successful planning and coordination between the state legislature, the Board of Regents, and university administrators, it provided an incentive for other state institutions. $^{7}$

In rapid succession, other universities established undergraduate libraries: the University of South Carolina, in 1960; ${ }^{8}$ Princeton, in $1961 ;{ }^{9}$ Cornell University, which undertook to convert a seventyyear old building into a modern library,

\footnotetext{
${ }^{5}$ Keyes Metcalf, "The Lamont Library," Harvard Library Bulletin, III (Winter 1949), 29.

"Robert A. Rohlf, "The Freshman-Sophomore Library at Minnesota," CRL, XIV (April 1953), 164.

7 Frederick H. Wagman, "Undergraduate Library of the University of Michigan," CRL, XX (May 1959), 179.

${ }^{8}$ J. M. Reames, "Undergraduate Library, University of South Carolina," Southeastern Librarian, X (Fall 1960), 130.

${ }^{\circ}$ W. W. Kuhn, “Princeton's New Julian Street Library," $\dot{C} R L$, XXIII (November 1962), 504.
} 
in September, 1962;10 the University of Texas, in 1963;11 and the University of North Carolina, which is scheduled to open its new Robert B. House undergraduate library in September 1968. ${ }^{12}$

In addition, the University of Illinois has completed plans for an undergraduate library to be opened on its Urbana campus in 1968. This library will be different in that it will be partly underground and will have a tunnel connecting it to the central library. ${ }^{13}$ The University of Oklahoma is in the first phase of planning a new undergraduate library building. ${ }^{14}$ Other universities also undergoing this first phase are Yale ${ }^{15}$ and the University of Wisconsin. ${ }^{16}$

In the Pacific Coast area, univerities also have been tending toward this same pattern of development. In February 1966, upon completion of the first phase of a five-year remodeling program, UCLA opened the doors of its college library as a separate library for undergraduates. The old red-brick campus landmark became a specific facility for the undergraduate student, housing a working collection of books carefully selected to meet his needs and offering staff and services specifically aimed to serve him. Across campus, a new and modern research library rises five floors to provide for the graduate students and research.

Late in 1966 Stanford University opened its new $\$ 4,870,000$ library for undergraduates. This three-story building of striking design will ultimately

\footnotetext{
${ }^{10}$ Cornell University Library. Annual Report 1962/63. Stephen A. McCarthy, librarian.

11 University of Texas, Texas Library Journal, XXXIX (Winter 1963).

12 University of North Carolina. Library. Annual Report 1964/65. John H. Gribbin, associate university librarian.

${ }^{13}$ University of Illinois, Illinois Alumni News, March 1966.

${ }_{14}$ University of Oklahoma. University of Oklahoma Library Staff Bulletin, XVII (March 1966).

15 Yale University. Yale University Bulletin, 1964/65.

${ }^{16}$ Wisconsin University. Library. Annual Report $1961 / 62$. Louis Kaplan, director of libraries.
}

house one hundred fifty thousand volumes and provide intimate reading and study areas for the undergraduate students of that university. ${ }^{17}$

The Berkeley campus of the University of California is also in the planning process and expects to complete an undergraduate library in $1968 .{ }^{18}$

Farther up the coast, the University of Washington is undergoing similar developments. In 1962 it began to develop an undergraduate book collection, which eventually will consist of about one hundred thousand titles. Initially, this collection is housed in the undergraduate reading room of the Suzzallo library; however, it is eventually to be transferred to a separate undergraduate library building which will be constructed near the Suzzallo library. ${ }^{19}$

\section{History of Development}

What are the circumstances that led to the establishment of separate undergraduate libraries? In order to provide background for the problem of library service to undergraduate students, it is necessary to look back to the time when most university libraries were small and were either informal or were organized for service on the alcove principle. This situation existed generally from the founding of American universities to the beginning of the twentieth century. Collections were small, the proportion of graduate students was small, and the library served both the graduate and the undergraduate more or less equally. Library service as we know it today did not exist, and the librarian was mainly a custodian. There were few problems at

\footnotetext{
17 Interview with David C. Weber, March 29, 1966.

18 California. University. Berkeley. Library. Annual Report 1963/64. Donald Coney, librarian.

${ }_{19}$ Marion A. Milczewski, "Beginnings of Undergraduate Library at the University of Washington," PNLA Quarterly, XXVII (October 1962), 19.
} 
the time, except perhaps the problem of collections.

Beginning in the 1870 's, the larger university libraries began to place emphasis on developing great research collections. Since the excellence of a university's library was measured by the strength of its research collection, librarians began to compete. As the collections grew, more and more emphasis was given to the research function of the university library. It necessarily followed that special service began to be given to the users of these collections-the research workers and scholars, and the undergraduate's library needs tended to be overlooked. ${ }^{20}$ His access to the collections began to be curtailed, and finally stopped, in many cases, and services to him became almost non-existent. During this time, according to Keyes Metcalf, "there is little indication that the University or the Library staff were greatly worried about the library service provided for the undergraduate except in a negative manner." 21 Librarians as a whole thought of themselves first as guardians and custodians of their collections, then as servants of the faculty and of such graduate students as attended their institution rather than of the undergraduates, for whom textbooks were somehow supposed to cover all literary needs. ${ }^{22}$

Prior to World War II, the common pattern of library organization and service in most American universities provided a central, general library which served faculty members, graduate students, and undergraduates-not equally, however. The library was designed as a center of bibliographical research ac-

${ }^{20}$ Arthur M. McAnally, "Library Service to Undergraduates: A Symposium," CRL, XIV (July 1953), 266.

${ }_{21}$ Keyes D. Metcalf, "The Undergraduate and the Harvard Library, 1765-1877," Harvard Library Bulletin, I (Winter 1947), 49.

22 Ibid., p. 47. tivity. It offered storage for great numbers of books, and study cubicles for the faculty and graduate students. Invariably, it "contained a cathedral-like, dimly lit main reading room," which usually housed the collection of reference works and "was furnished with long tables and chairs." "The reference department was often housed in this room" and had the task of handling service for the entire community of users. "The stacks were closed to the undergraduates," partly because it was felt that "the scholarly volumes had to be protected and also because no library could afford the shelf-reading entailed in granting" free access to books to "thousands of inexperienced students." The provision of separate reading rooms and added seat 'space in branch libraries was looked upon as solving the problem of undergraduate library needs. ${ }^{23}$

Very few institutions offered specialized provisions for undergraduates. Some had set aside special reading rooms, either within the central building or elsewhere, in which frequently used materials were concentrated in one location. There were a few instances of a separate small collection, as at Columbia and Chicago, where the college library included a small reference collection as well as supplementary and background reading material. Even with these provisions, however, it was generally true that the undergraduate was on his own and had to find his library collection and services in competition with all other users in the central library. ${ }^{24}$

In the 1930's, some far-sighted librarians began to realize that in the process of developing their great collections and striving for distinction as centers of advanced study they had neglected the

\footnotetext{
23 Wagman, loc. cit., p. 179.

${ }^{24}$ Stephen A. McCarthy, "Library Provision for Undergraduates in the U.S.," CRL, XXVI (May 1965), 223.
} 
undergraduate and that one function of the library was not being fulfilled-that of education of the undergraduate student. Consequently, in the next decade, increased services for the undergraduates were generally undertaken. Libraries increased their reference and loan staffs in an attempt to give more and better service to the undergraduate; they set up information desks and increased instruction in library use for him. With the coming of the great boom years following the war, however, it became apparent that although these were valuable services, they were still short of what the undergraduate needed: a relatively small collection of books, carefully selected to satisfy the ordinary needs of general reading and instruction, available in open stacks, conveniently located, and informally administered by a friendly and competent staff. ${ }^{25}$

This need was clearly pointed out by the success of the small college library, which was succeeding where the large university library had failed. Realistically aware that it could not attempt to provide research material, the small library concentrated on the best possible integration of the library with the academic program of its institution and was thus serving its undergraduates better than the more renowned library of the larger university. ${ }^{26}$

Equally as urgent a problem as the need to provide service to the undergraduate has been the need for increased space in libraries in the past two decades. The tremendous growth of enrollment that occurred in American universities during the postwar years was a major factor that influenced the development of separate undergraduate libraries. Since 1930, there has been a steadily increasing student enrollment in the colleges and universities of the

25 Wagman, loc. cit.

${ }^{28}$ R. C. Swank, "Four Studies of Universitv Library Problems," CRL, XIII (June 1952), 62.
United States. Among eighteen to twenty-year olds in the nation:

In 1930 . . . 72 out of 1,000 were enrolled in colleges and universities. In 1940 . . . 91 out of 1,000 were enrolled in colleges and universities. In 1950 . . 168 out of 1,000 were enrolled in colleges and universities.

In 1960 . . 250 out of 1,000 were enrolled in colleges and universities. Thus, in a period of thirty years there has been an increase of enrollment of approximately 247 per cent. ${ }^{27}$ The increases were the result both of population growth and the rising percentage of high school graduates who elected to go to college. The percentage of young people 18-24 years of age who were enrolled in college in 1960 was roughly the same, 25 per cent as that of high school enrollment in 1917. ${ }^{28}$

This steadily increasing influx of students naturally began to create grave space problems in many university libraries. As pressure for space became greater and greater, relief had to be obtained in some manner. Additions, new construction, remodeling of old buildings -all were needed and undertaken. In each institution which has provided an undergraduate library there was a serious need for additional library space. ${ }^{29}$ The separate undergraduate library proved to be an excellent means of providing some of the needed space.

\section{The Undergraduate Libraries of} Harvard, Michigan, aNd UCLA

Even with the establishment of a separate library building, there is no one solution to the problem of under-

\footnotetext{
${ }^{27}$ Lewis Branscomb, "Libraries in Larger Institutions of Higher Education," Library Trends, X (1961), 188.

${ }^{28}$ U.S. Dept. of Health, Education, \& Welfare. Progress of Public Education in the United States of America, 1959-60 (Washington, U.S. Govm't. Print. Off., 1960), p. 11 .

${ }_{29}$ McCarthy, loc. cit., p. 224.
} 
graduate library service in a university. Institutions differ in their organization, finances, building facilities, and curricula. In view of these factors, each university must determine its own method of library service, its own needs and possibilities, and must set its own pattern.

To understand better the functions of an undergraduate library, this paper will survey three such libraries-the Lamont, the undergraduate library at Michigan, and the college library at UCLA. The Lamont and the undergraduate library at Michigan were the first two libraries to be built. The Lamont catalog and the shelflist of Michigan have been used continually since their issuance as guides in book collections for college libraries. Of special interest is the college library, which formally opened recently at UCLA. These three libraries exemplify distinct types of undergraduate libraries. The Lamont is a library made possible through endowment funds in a large and financially wealthy private institution. The undergraduate library at Michigan is a new building constructed for undergraduate use with public funds made available through effective planning and cooperation between the state legislature, the Board of Regents, and the university administrators. UCLA's college library, another state-financed library, is an example of the conversion of an old main library to undergraduate use.

Lamont Library. The idea of such a library was not new; Harvard college records of 1765 contain the first reference to the need for separate library facilities for the undergraduates. In the Harvard Library Bulletin a series of articles on the history and development of library service at Harvard traces the persistent growth of this idea. The dedication of the Widener library in 1915 did not solve Harvard's space problem completely, and twelve years later the di- rector cited the need for even more space. Also it was found that Widener had many drawbacks for undergraduate library service, and the increased demands of faculty members, graduate students, and visiting scholars was pushing the undergraduates further and further into the background.

By 1937 the space problem was acute and Librarian Keyes Metcalf recommended a four-point program, which included the building of a separate undergraduate library. ${ }^{30}$ Five reasons for such a library were given. (1) The "very great scattering of reading room facilities [there were library facilities of some importance in forty different buildings] reduces the use of the Library by the undergraduate. ..." It was felt that if the undergraduate could "go to one building . . , and find there all the material for assigned collateral and general reading that he needs . . ., he will make use of books." (2) The "central collection is so large that it cannot be opened to the undergraduate except under very special circumstances, and as a result there is no large general collection freely accessible to the undergraduate at Harvard." (3) To obtain books from the central collection, the student had to use the large public catalog, which contained some five million cards, with complexities of arrangement that presented difficulties even to the faculty and staff. A large proportion of freshmen found the catalog so perplexing and overpowering on their first attempt to use it that they gave up and never tried again. (4) The attempt to combine library services for the undergraduate and graduate students in the same room had never worked out successfully at Harvard, or elsewhere. It seemed to result generally in the undergraduates being neglected because of the intensity of the demand by the older groups. (5) Even more

${ }^{30}$ Philip J. McNiff, "Lamont Library, Harvard College,", CRL, XIV (July 1953), 269. 
pressing than the other four arguments was the question of needed space for book storage, for staff, and for undergraduates. ${ }^{31}$

It was decided that the construction of a building for the undergraduates would be cheaper than a new central building and that it would be the only satisfactory solution to the problem of library facilities for undergraduates. Consequently, on February 6, 1940, the Administrative Board of the College voted approval for a special library for undergraduates. All that remained was to raise the money. During the following years, Librarian Metcalf brought up the matter at various meetings of alumni. At a meeting in the Harvard Club in New York City, the librarian was seated beside Thomas W. Lamont, '92, and told him in some detail of the plans and hopes for the undergraduate library. Mr. Lamont expressed great interest. Correspondence between Mr. Lamont, President Conant, and the librarian continued; and in 1945 President Conant was able to announce that Mr. Lamont had given the University $\$ 1,500,000$ to be used for the construction of an undergraduate library. ${ }^{32}$

Careful planning went in to the construction of the Lamont library, for there were no traditional lines to follow. The philosophy on which the functioning of the library was based required that it be conveniently located and inviting to the undergraduates. An efficient ventilating system, good lighting, a building made quiet by sound-absorbing ceilings and floors, inviting color, and a variety of reading accommodations were all incorporated in plans to make the library attractive. Extra-curricular interests in books and reading were encouraged further by such features as book displays, record-playing facilities, a browsing

\footnotetext{
${ }^{31}$ Keyes D. Metcalf, "The Undergraduate and the Harvard Library, 1937-1947," Harvard Library Bulletin, I (Autumn 1947), 295-97.

32 Ibid., p. 302.
}

room and collection, and a printing room. Simplified cataloging and a numerical classification scheme with not more than one decimal place were used in order to make it easier for students to find books. ${ }^{33}$

The objectives of the library were specifically stated: (1) to concentrate as far as was practicable the library service for undergraduates in a central location; (2) to make the books readily available to the students; and (3) to encourage general and recreational reading as well as to supply required and collateral reading. ${ }^{34}$ In addition, there was the fact that the establishment of a separate undergraduate library was the most suitable way of obtaining relief from the pressure upon the central library and so of making the latter a satisfactory center for research activities.

Over the past seventeen years, staff experience and student response seem to indicate that the Lamont library has fulfilled these objectives and that its successful use has proven Mr. Metcalf's premise that "the undergraduates will make more and better use of a library designed expressly for them." 35

Undergraduate Library of the University of Michigan. "It was all very well for Harvard" with its great private resources "to build the Lamont Library." But could state university libraries, "with inadequate book budgets, with library buildings inferior to Widener, and with several times as many undergraduates as Harvard, hope to follow the example," no matter how worthwhile it might sound? Donald Coney, writing about the Lamont library after it opened observed that it would not be easy for the larger

\footnotetext{
${ }^{33}$ Metcalf, "The Lamont Library," loc. cit., pp. 29-30.

${ }^{34}$ Metcalf, "The Undergraduate and the Harvard Library, 1937-1947," loc. cit., p. 305.

${ }^{35}$ Keyes D. Metcalf, "Harvard Faces Its Library Problems," in The Place of the Library in a University, A Conference Held at Harvard University 30-31 March, 1949 (Cambridge: Harvard University Library, 1950), p. 42 .
} 
state universities to duplicate the Harvard structure. $\mathrm{He}$ estimated that it would require a minimum of four and a quarter million dollars to provide a library of the Lamont type for the University of California at the Berkeley campus. He said:

A Lamont Library can be realized on state university campuses only if administrators and librarians are skillful in presenting the library needs of the state's youth so persuasively that legislatures will see the light, for it is to state legislatures-and not to private wealth-that the state universities must turn. . . . More important than this act of persuasion, however, is a decision which must be taken earlier, and by librarians and university administrators. I mean the decision that, important as it is to have libraries for books, it is also important to have libraries for people. ${ }^{36}$

The University of Michigan solved this problem successfully and on January 18 , 1958 , opened its undergraduate library, the second such building to be constructed in the country. To do so, in 1952 the university had to "set aside a plan, developed over about a decade, for the enlargement of its general library building. The remodeling and expansion of this building, at very high cost, would have improved it greatly for use by the graduate students and faculty but would not have provided for improved undergraduate" services. ${ }^{37}$ Instead, it was argued that the undergraduate enrollment, which could not be controlled in a state university, might be more than 20,000 by 1970 and that expansion of undergraduate library facilities was extremely urgent. It was decided that Michigan must try to offer the benefits of a good small college library for its undergraduate students; therefore, a substitute

\footnotetext{
${ }^{36}$ Donald Coney, "The Future of Libraries in Academic Institutions," in The Place of the Library in a University: A Conference Held at Harvard University 30-31 March, 1949 (Cambridge: Harvard University Library, 1950), p. 55 .

${ }^{37}$ Wagman, loc. cit., p. 183.
}

program was drawn up calling for some remodeling of the general library and for the construction instead of a separate undergraduate library building. This new program was given high priority from the beginning and had the strong support of the Board of Regents and the State Legislature. ${ }^{38}$

"The program written subsequently for this undergraduate library stated, as basic principles, that everything possible should be done in the architectual planning and in the selection of books and staff to make the library inviting and easy to use; to give the students the impression that the librarians were employed to assist rather than supervise or monitor them; and to help the undergraduates develop a proprietary interest in their library." ${ }^{39} \mathrm{~A}$ new modular building was constructed which provided a maximum flexibility of space in its five floors. "Lighting, air conditioning, and liberal provision of electric and telephone outlets will make possible the erection of partitions in almost any pattern desired in the future." The entire book collection was placed on open shelves. Reserves "were placed where they belong in the classification system, on the open shelves," and marked with "a distinctive symbol. . . ." Controlled exits from the building preserved the safety of the collection. Seating in small units of four and eight students was provided by the use of small study rooms, "by the ranges of book shelving," and by placement of screens. ${ }^{40}$

The book collection was selected "with the aid of hundreds of faculty members" over a period of several years; "an initial stock of 60,000 volumes and 150 periodical titles was assembled and cataloged." Since the entire collection was con-

${ }^{38}$ Frederick H. Wagman, "The Case for the Separate Undergraduate Library," CRL, XVII (March 1956), 154.

${ }^{39}$ Wagman, "The Undergraduate Library of the University of Michigan," loc. cit., p. 184. 
sidered a browsing collection, "no separate browsing collection was provided." A "substantial collection of reference books was placed on the open shelves" for easy access "to both staff and students."

In addition, special rooms were provided for other library materials. There was a room "for listening to recorded music, poetry, and drama. . .." "A multipurpose room equipped with 200 stacking chairs, motion picture projectors, and public address system" was provided for use "by the students" for lectures, discussion groups, motion pictures, or for any affair "which concerns undergraduates and the library." On the main floor an exhibit area was provided for monthly shows by the Fine Arts Museum. "On the top floor a large display room was made available to the fine arts department." 41

In the first year of its operation, the response of the undergraduates to their library "was overwhelming. . . ." "The rate of both building and book use" climbed steadily and has continued to climb with each successive year. Other effects of the library are noteworthy. "It has definitely become the hub of undergraduate activity on the campus. Its central location" makes it possible for students to spend more hours between classes reading in the library. "The undergraduates are reading a great many more good books than before and under the guidance of the reference staff . . . are learning how to use a library catalog, indexes and bibliographies, and other reference works." According to Frederick Wagman, director of libraries at Michigan, "the effect of this library on the students has been extremely gratifying." 42 Its "success has stimulated the students to plan the development of small

41 Ibid., p. 185.

12 Ibid., p. 187. libraries in the dormitories which they will administer themselves."

Its effect upon the faculty "has been equally interesting." An "increasing number of members of the faculty" are "teaching with books," and the faculty interest in using the library as an aid to their teaching has begun to exceed the library's ability to keep up. ${ }^{43}$ In addition, the general library has become predominantly a library for graduate students and the faculty and has provided them with better service because of this specialization.

UCLA's College Library. In contrast to the previous two undergraduate libraries, which had completely new buildings constructed and designed expressly for their purposes, the UCLA college library found its home in the old main library building on the campus. Its intent, however, was similar: to adopt a philosophy of ready access and attention to individual needs so that it would become an effective and encouraging teaching instrument for undergraduate students. ${ }^{44}$ Extensive remodeling was undertaken on the old building, which was built in 1929 and is of the monumental type of architecture that was popular at that time. It has a grand central stairway, a large rotunda, and a central stack well that occupies the entire core of the building. Its heavy fixed walls are inflexible and not susceptible to modification or expansion. It is, however, a distinguished and ornate building of Lombardian Romanesque style, with an elaborate front facade and a striking octagonal dome on the structure and an equally elaborate interior. Such a building was more appropriate to house a small and fixed collection, such as that of the undergraduate library, than a huge and continuously growing research collection. The beauty and tra-

4 Ibid., p. 188.

4 California. University. Los Angeles. Library. Annual Report 1961/62. Robert Vosper, librarian. 
dition of the building, also, it was felt, would provide an inviting atmosphere for the undergraduate student. For the purposes at UCLA, therefore, it was a happy solution to convert this building into the undergraduate library and to build a new and modern functional building to take care of the research collection. ${ }^{4}$

Like Michigan, UCLA is a state-controlled institution which has to depend upon the State Department of Finance and the state legislature for the money to support its building programs. In direct contrast to the situation at Michigan, in which the state legislature gave full and strong support from the beginning to the program for construction of a new undergraduate library, the UCLA administrators were plagued with consistent difficulty in getting financial allocations from the State Department of Finance for the badly needed expansion and remodeling program. The reluctance of this body to provide funds for these projects appeared to stem from a lack of recognition and support in the legislature of the needs of the library. It was only after years of often frustrating and determined effort that plans were drafted, finally approved, and construction was begun. ${ }^{46} \mathrm{~A}$ twenty-five year building program, started in 1948, was abandoned in 1957 when it became apparent that the inflexible old building never could be expanded or remodeled satisfactorily to take care of a great research collection. ${ }^{47}$

In 1960 plans for a new research library were completed and approved. Upon the funding of its first unit, construction was begun in 1962. At the same time, a rider was attached to the funding of Unit I which allowed for a

\footnotetext{
45 Interview with Norah Jones, April 21, 1966.

46 California. University. Los Angeles. Library. Annual Report 1961/62.

17 Report on remodeling in the 50's, prepared by Robert L. Quinsey. UCLA. May 14, 1950. (Untitled)
}

five-year remodeling plan to transform the old main library into an undergraduate library. ${ }^{48}$ With the completion of Unit I of the research library in 1964, remodeling was begun on the college library. The remodeling of this library was originally planned as a one-stage project, but because of a sharp increase in cost estimates, it had to be phased in three separate units. The first phase of this remodeling was completed in January 1966, and the college library formally opened as an undergraduate library.

The idea of an undergraduate library at UCLA first took form in December of 1948. The pressure of increasing student enrollment and use of the library was already beginning to be acutely felt by the library, and its complexity was beginning to interfere with service to the undergraduate students. An openstack undergraduate library, therefore, was set up on the ground floor of the main library; this separate room used a portion of the adjoining central book stack to provide its own beginning collection of collateral and recreational reading. Plans were also beginning to be formulated to add a separate west wing to the main building as an undergraduate library. ${ }^{49}$ In 1958, the creation of the college library was officially announced with the amalgamation of the reserve book room and the undergraduate library into a new administrative unit -to be officially called the college library-under the direction of Norah Jones. ${ }^{50}$

In the remodeling of the college library, every attempt was made to make it informal and inviting to the under-

\footnotetext{
48 California. University. Los Angeles. Library. Annual Report 1958/59, 1959/60. Lawrence Clark Powell, librarian.

- Neal Harlow and Everett T. Moore, "UCLA's New Wing But the Beginning," Library Journal (June 15, 1949) 971-73.

50 California. University. Los Angeles. Library. Annual Report 1957/58. Lawrence Clark Powell, librarian.
} 
graduate. The huge, cathedral-like old reading room was remodeled and broken up by bookcase dividers into smaller reading areas, which creates an alcove effect around the large rectangular room. These alcoves are to serve as individual reading rooms, and the bookcases surrounding each one will house the literature of a specific country. A separate lounge with comfortable chairs and tables arranged in small reading groups was set up in the large foyer, and a browsing area of recreational reading material was provided. Free access to books and a selected group of periodicals was made available to the undergraduates. A separate reference collection is set up in the main reading room; the reference desk is to be found in the center of that room directly facing the entrance. It opens on all four sides so that the reference librarian can get out from behind it to work with the students. New and comfortable furniture in a contemporary style was provided and better lighting facilities were added. Controls were arranged so as to restrict only the open stacks and main reading room area; free access was afforded to the reserve book room, study halls, and other facilities housed in the building. ${ }^{51}$

At opening, the collection consisted of seventy thousand volumes of a working collection already in use and contributing directly to the undergraduates' needs of general reading and instruction. This will be built to a maximum collection of two hundred thousand volumes, which will be maintained at that level through thorough weeding. A selected group of periodicals is also included. The library has its own separate catalog, which is conveniently placed before access to the stacks. ${ }^{52}$

The college library has been open too short a time to provide an effective eval-

${ }^{51}$ Interview with Jim Davis, April 19, 1966.

52 Interview with Norah Jones, April 21, 1966. uation of its effects on the campus. Its establishment, however, serves notice that the undergraduate has not been overlooked at UCLA, even though the primary concern of that institution is its research collection and its increasing graduate study programs. The undergraduate is provided a core collection of general books to meet his general needs. With his own building, he finds a more relaxed atmosphere and a reference department whose function is to serve his needs alone. That function is more concerned with teaching and guidance and seeing that he gets a command of the literature at hand. In this environment, the undergraduate will first learn to handle a smaller collection selected for him; then he will be able to step up to the massive and complex research collection. ${ }^{53}$

\section{Conclusion}

Unlike the research library, and undergraduate library limits its materials to those which contribute directly to the undergraduate's needs. A small openshelf library with convenient access has little in common with the massive collection of materials found in a great research collection and approached through intricate catalogs and bibliographies. The previous discussion serves to point out that a separate undergraduate library has become an accepted part of library planning in a great number of large universities of our country for essentially like reasons wherever it is found.

The first and most obvious reason a university should have an undergraduate library is a pressing need for space. When book collections and the number of readers to be served become very large, it is desirable to break up the collection and readers into smaller, more manageable units. The undergraduate

\footnotetext{
${ }^{53}$ Interview with Norah Jones, April 21, 1966.
} 
library is an effective means of making such a division.

The second reason is that it allows the university library to serve better the needs of its undergraduates. Such an undergraduate library facilitates assigned reading and encourages browsing and personal interest reading; it provides specialized reference services and a full range of working materials close at hand and immediately available.

At the same time, these gains have their counterpart in other areas of university library service. Additional space for graduate study and research also becomes available and a better concentration can be made of bibliographical aids, catalogs, and indexes to serve the graduate and advanced student needing intensive or specific information for his investigation.

If the undergraduate is not frustrated by the complexities of the large research collection, he is more often thwarted by being denied access to it. In his own library he is provided free access to a smaller collection and the opportunity to learn library materials and procedures. Such an experience can serve as a step for him to the difficult and massive research library which he will presently need.

The undergraduate library provides the faculty with a better opportunity to teach with books. A collection specifically selected and made easily available enables the faculty to assign more and more outside reading to supplement their instruction. The lecture-and-textbook system of instruction will not be used so much as a matter of necessity; the student can be given more freedom to work on his own with source materials in the library.

A very practical value can be found also to weigh in favor of the separate undergraduate library. Its existence is a means of combatting the image of a great, cold, and impersonal multi-university. A separate library calls attention to the fact that the undergraduate is recognized as needing special attention and study facilities of his own which provide a minimum of regimentation.

It should be noted again that not all universities consider the separate undergraduate library as the best possible solution to the problem of space and undergraduate needs. Some, such as Columbia and Rice, favor the alternative solution of setting up a separate collection within the confines of one entire library. All support the idea that some separate service is needed for the undergraduate; the controversial issue is whether a separate building is desirable.

By placing the undergraduate in his own environment, he is removed from the intellectual stimulation of the research collection. By providing him with a "small undergraduate collection," he is restricted and will not learn to venture outside these limits. These two arguments are consistently raised against the separate library. ${ }^{54}$ William Dix, former librarian at Rice and now librarian at Princeton, argues that the function of the university library should be education and not facilitating access to the "best" (or selected) books on a subject. Direct exposure to a large book collection, not one specially selected for him, is considered a valuable educational experience for the undergraduate student. As part of his educational process, he should be constantly confronted by books a little beyond his grasp; by becoming aware of their existence, there is the chance he might be led into deeper waters. Such an effect, Dr. Dix contends, cannot be produced if the undergraduate works entirely with a few basic books or with a small collection supposedly within his grasp. ${ }^{55}$

\footnotetext{
54 "Library. Service to Undergraduates: A Symposium," CRL, XIV (July 1953), 266-77.

${ }^{55}$ Dix, loc. cit., p. 271.
} 
Dr. Dix's philosophy can apply very well in a small university library of less than half a million volumes. The unified collection can be housed adequately in one central library, and the students can be given access to the total collection. In this case, with a little care and planning, there is no reason for the undergraduate to become lost.

In large universities with extensive research collections and great masses of students, both at the graduate and undergraduate level, however, an entirely different situation exists. The undergraduate student, overwhelmed by both of these factors, is fast becoming a "second-class library citizen," 56 and a new kind of provision must be made for him. The undergraduate library is an

Bo California, University. Los Angeles. Library. Annual Report 1961/62. Robert Vosper, librarian. effort to correct library errors of the past in regard to the undergraduate student and to provide him with a new investment in learning. The success of such a library depends largely upon two things: it must be inviting and stimulating, both as to building, collection, and staff; and it must be interpreted not as a substitute but as an extension of the main research library, designed for the special benefit of the undergraduate student.

The development of the undergraduate library has been nationwide; rather than being the result of any separate local conditions, it is an outgrowth of large universities in the United States today. A definite trend is in motion which will in all probability see the establishment of the two-library pattern on many other large university campuses in the future.

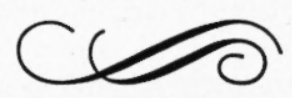

